\author{
Marquette University \\ e-Publications@Marquette
}

4-2014

\title{
Language as the House of Being? How to Bring Intelligibility to Heidegger While Keeping the Excitement
}

Pol Vandevelde

Marquette University, pol.vandevelde@marquette.edu

Follow this and additional works at: https://epublications.marquette.edu/phil_fac

Part of the Philosophy Commons

\section{Recommended Citation}

Vandevelde, Pol, "Language as the House of Being? How to Bring Intelligibility to Heidegger While Keeping the Excitement" (2014). Philosophy Faculty Research and Publications. 417.

https://epublications.marquette.edu/phil_fac/417 


\title{
Marquette University
}

\section{e-Publications@Marquette}

\section{Philosophy Faculty Research and Publications/College of Arts and Sciences}

This paper is NOT THE PUBLISHED VERSION; but the author's final, peer-reviewed manuscript. The published version may be accessed by following the link in the citation below.

Philosophy Compass, Vol. 9, No. 4 (April 03, 2014): 253-262. DOI. This article is (C) Wiley and permission has been granted for this version to appear in e-Publications@Marquette. Wiley does not grant permission for this article to be further copied/distributed or hosted elsewhere without the express permission from Wiley.

\section{Language as the House of Being? How to Bring Intelligibility to Heidegger While Keeping the Excitement}

\author{
Pol Vandevelde
}

Philosophy Department, Marquette University, Milwaukee, WI

\begin{abstract}
At the core of Heidegger's philosophy, there lies this nagging question: what is the link between language and being? Using a famous formulation by Heidegger as a guide ('When we go to the well, when we go through the woods, we are always already going through the word "well", through the word "woods"'), the analysis focuses on the connection Heidegger establishes between being (what woods and well 'are'), understanding (something is understood 'as' woods or well), and temporality (human understanding of woods and well has changed since ancient Greek times, for example). Language is both what grants things their way to matter to us and thus to 'be' for us to the extent that we understand them, but language is also linked to a 'happening' (Geschehen) or an event so that things are not bound to their Geek being or current being: things 'become being' (seiend werden). Language is both the means for things to materialize in historical times: 'being woods' or 'being a well,' as well as a testimony to their entry into being. This is why language in its poetic use can make beings 'more being' (seiender).
\end{abstract}


Martin Heidegger is one of those thinkers who have questioned at their roots the most fundamental distinctions of philosophy. Such a radical challenge requires its own style of formulation, what Walter Benjamin calls its 'mode of meaning' (die Art des Meinens) (Benjamin 59). The content of Heidegger's 'philosophy' cannot be separated from the performance involved in formulating it. To some degree, this holds true for all 'thoughts', but Heidegger was one thinker who, besides pioneering a certain style of philosophizing, also reflected upon it and made a case for it. His particular style has left commentators to wonder what to do with formulations such as 'language speaks' $(\mathbf{1 9 5 9 , 1 2 0 )}$ or 'language is the house of being' $(\mathbf{1 9 7 6 , 3 1 3 ) . ~ T h e y ~ s o u n d ~ p o e t i c ~ b u t ~ t h e y ~ a l s o ~}$ seem to promise a conceptual yield. In the first part, I briefly sketch the difficulties commentators encounter when dealing with Heidegger's 'mode of meaning'. In the second part, I suggest a way to make sense of the connection Heidegger establishes between being, language, and event.

\section{The Sirens among Interpreters}

If we as interpreters want to remain neutral observers, expecting to find out the content 'expressed' by Heidegger's formulations, we will quickly lose patience and dismiss his conceptual-poetic language, as many philosophers and linguists have done. On the side of philosophy, early on, Theodor Adorno criticizes the 'jargon of authenticity' (1973), Rudolf Carnap ridicules the misuse of language (1959), and Karl-Otto Apel detects a 'linguicism' in Heidegger's musings about language $(\mathbf{1 9 6 3}, \mathbf{8 8})$. On the side of linguistics, Mario Wandruszka diagnoses a 'pathological hypermotivation' in Heidegger's use of etymologies (1978) and Henri Meschonnic discerns an 'oneiric logic' in his play on words (1975). We could also mention writers such as Günter Grass who gives us a devastating satire of Heidegger's talk in the mouth of a Nazi sympathizer in his novel Dog Years (1963). However, even among those who take Heidegger seriously, his own language has been a cause for some concern. The French translation of Being and Time by François Vezin led to a fierce and very public critique in the form of an open letter, signed by many Heidegger scholars, in the newspaper Le Monde (January 16, 1987). Similarly, the English translation of Contributions to Philosophy by Parvis Emad and Kenneth Maly (1999) encountered some concerns about its neologisms and has been followed by a second new translation by Richard Rojcewicz and Daniela Vallega-Neu (2012). Heidegger's Contributions has been hailed as a second Magnum Opus by Otto Pöggeler or downplayed by many commentators for its obscure style. Of those who take it seriously, it is described as a set of 'stern experimentations' with a 'singular, sometimes maddening, always demanding quality of judgment and affirmation' (Scott 5) or as 'an arrangement of 281 opaque notes and fragmentary sketches', the language of which 'is hypnotically repetitive and dense, consisting of formula after formula' (Polt 2006, 2).

Such a challenging but original and fascinating style of philosophy has motivated innumerable efforts by interpreters to 'situate' Heidegger's thought. Apel (1989) has detected several phases in Heidegger's influence since the publication of Being and Time. Originally, Heidegger was received as an existentialist, especially in France, where his philosophy of existence that emphasizes authenticity and being-toward death became popular. Later, his fundamental ontology gained traction as an attempt to renew ontology through a hermeneutic turn in philosophy. Another phase of Heidegger's influence rests in the 'destruction' of Western metaphysics and its predisposition for a form of thinking that has prepared our technological era. According to Apel, this is how Heidegger has influenced a postmodernist critique of modernity or what has been called 'postmetaphysics'. This has led to a convergence between French and Italian postmodernism (Lyotard 1984; Derrida 1982, 1989; Vattimo 1993), American neo-pragmatism (Rorty 1991), and some trends in philosophy of science (Kuhn 1962).

If we want a finer-grained analysis and wonder about Heidegger's influence when it comes to the question of language, the challenge is rather daunting. There is the Heidegger of ontological linguistics, as Johannes Lohmann (1948) extensively explored it in the grammar of Western languages, the Heidegger of literary studies 
(Staiger 1991; Allemann 1954), the Heidegger of the philosophy of art (Gadamer 1989), and the Heidegger of deconstruction as used and mined by Paul de Man (1983) and Jacques Derrida. Two collections of essays illustrate the contemporary variety and multiple perspectives taken on Heidegger. The first collection, edited by Hubert Dreyfus and Mark Wrathall (Heidegger Reexamined, vol. 4 Language and the Critique of Subjectivity, 2002), contains essays on topics such as the ego, the epistemology of moods, logic, the intentionality of language, other minds, validity, and the connections between Heidegger and Davidson, Carnap, Frege, or Wittgenstein. The second one, edited by Jeffrey Powell (Heidegger and Language, 2013), arises from a more continentalist perspective and addresses topics such as silence, homeland, the essence of language, as well as connections between Heidegger and Homer, Plato, Aristotle, Hölderlin, Blanchot, or Lacan. Such a variety of perspectives does not go without antagonism, as illustrated, for example, by Dreyfus's critique (2002) of Cristina Lafont's view (2000) that meaning determines reference, which, for Dreyfus, is a total misunderstanding of Heidegger.

Among all these trends and influences, the challenge for Heidegger scholars is at least twofold: positively, they want to make his formulations conceptually intelligible so that his views have currency in contemporary philosophical discussions, but at the same time and negatively, they do not want to ignore the very formulations Heidegger uses. In short, those sympathetic interpreters have to make Heidegger intelligible without ruining the powerful language that has fascinated them in the first place. Donald Davidson has pointedly formulated how this is indeed a challenge. He says: 'The trouble is, as so often in philosophy, it is hard to improve intelligibility while retaining the excitement' (Davidson 183). This is all the more challenging in the case of Heidegger because interpreters have to make use of the many dichotomies that have been the paraphernalia of much philosophical practice, such as poetic v. conceptual or logical judgment v. linguistic expression; interpreters also need to relate to the so-called 'perennial problems' of philosophy, such as freedom v. determinism or being $\mathrm{v}$. becoming, while Heidegger superbly ignores the former - traditional philosophical dichotomies - and rejects the latter - the perennial problems of philosophy.

In order to respond to Davidson's challenge, I try to account for the aspect of performance that thinking has and follow Heidegger's invitation to think together the question of being, the question of history, and the question of language. My aim is to delineate the stakes of linking these questions in order to show why these questions cannot be dealt with by using traditional philosophical dichotomies or appealing to perennial problems of philosophy. I choose as a test one of Heidegger's formulations that combines the performance of thinking with the description of such a performance: "When we go to the well, when we go through the woods, we are always already going through the word "well," through the word "woods," even if we do not speak the words and do not think of anything relating to language' $(\mathbf{1 9 7 1}, 132)$. In this 'mode of meaning' (Benjamin), which is poetic and holds a conceptual promise, the poetic aspect is not accidental or secondary to the conceptual aspect but gives traction to thought and is supposed to accompany us and even lead us to see what Heidegger's words point to. Here, however, as with all fascination, comes temptation.

The first temptation for interpreters can be called 'Frege's choice': either we are interested in truth and turn to scientific propositions or we are interested in artistic consideration, at which point we abandon truth. Using a sentence from The Odyssey as an example, 'Odysseus deeply asleep was disembarked at Ithaca', Frege writes: 'in listening to an epic, for example, we are fascinated by the euphony of the language and also by the sense of the sentences and by the images and emotions evoked. In turning to the question of truth we disregard the artistic appreciation and pursue scientific considerations' (Frege 221). It happens that none of the latter is to be found in the sentence from the Odyssey because the name 'Odysseus' does not have a real referent. Since, in the case of Heidegger, the poetic manner of saying is part of the flesh of the conceptual substance, Frege's choice would force us to choose between two equally unpalatable options. On the one hand, we can translate Heidegger's own language into a propositional form. This will bring about some level of intelligibility, but it 
would, at the same time, certainly kill the excitement, as surely as turning a poem into a set of propositions. On the other hand, we can preserve the poetic aspect of Heidegger's language against conceptual encroachment and, following Frege's choice, abandon any concern for truth. This second option would avoid conceptual violence but might lead us merely to repeat, rephrase, paraphrase, and parse Heidegger's statements to death, turning them into pronouncements and making of Heidegger another obscure Heraclitus: Heidegger the skoteinos, the bard of the equally Black Forest. Thus, with Frege's choice, either the propositional Heidegger turns us, interpreters, into unexciting practitioners of a new scholastics, or the poetic Heidegger leaves us no choice but to become philologists, in both cases abandoning the field of philosophy altogether.

Besides Frege's choice, there is a second temptation: to downplay 'the mode of meaning' (die Art des Meinens) and focus not so much on propositions of a scientific stature, as in Frege's choice, but rather on topics and issues; in short, the temptation is to apply Heidegger to metaphysical issues, ethical issues, technology, the environment, pragmatism, externalism and internalism, etc., in short, 'real issues.' In line with Frege's dismissal of the Odyssey when it comes to truth, this can be called 'the sirens' temptation' of contemporary relevance: through application, we make Heidegger relevant and a partner in contemporary philosophical discussions. In this process, however, we may lose the capacity Heidegger has given us in the first place to question the privileged framework of reference chosen, the assumptions that go with our contemporary approach to what metaphysics is supposed to be about, in its discussion of realism v. anti-realism or the mind/brain. The price to pay when buying wholesale into application or what is called 'applied philosophy', is, for example, to consider ethics as a technique for solving puzzles, preferably science-fiction ones, real issues likely to include too many variables extraneous to the aspect under discussion. When philosophy is done in such an applied mode, Heidegger's works are mined for ideas or insights that are reframed in a more intelligible conceptual form - in the analytic mode - or a more fruitful social and political agenda - in the feminist, gender theory, race studies mode-and the formulations are spit out as indigestible adornment or metaphorical fiber. We are then left with an updated Heidegger, but one who has, for many of us, lost his bite. When these issues have become, as we say, 'issue ads', the subversion is gone, and the challenge has been blunted. Philosophy continues its academic path, torn among the different factions and turf battles for relevance, but without any need for courage. Courage lies in framing the issue, not in choosing a camp among anonymously pre-established positions. Or courage consists in the 'poietics' of thought, producing new ways to look at things and issues, not in the retail business of pre-packaged thoughts.

We want to face these two temptations - Frege's choice and the sirens of relevance - without succumbing to them; we would thus like to avoid the Scylla of scholasticism and philology - translating Heidegger or parsing him to death - without falling into the Charybdis of application - using Heidegger for dealing with pre-'sorted' or pre-'triaged' 'issues'. In short, we wish to make Heidegger intelligible without flattening out what he says refusing to choose between the poet or the thinker - or we trust that, when made intelligible, what he says will not sound pedestrian and bland. Like Ulysses before disembarking at Ithaca, we want to avoid Scylla and Charybdis and still enjoy the sirens' song but without tying ourselves in knots.

\section{Being, Language, and the Event}

Our test was the statement that when we go to the woods, we always go through the word 'woods'. This sentence connects being - in this case: the woods, to which we relate by walking in them - to language, in the form of 'going through the word "woods".' Such a connection is not static or conceptual: it is a performance of 'going through' both the woods and the word 'woods'. The 'going-through' as a performance is an event; it is something that happens; it takes place. This connection between the word, the woods, and the event or between language, being, and history was not a later concern for Heidegger. It was in fact what, by his own account, motivated his whole intellectual journey and which started specifically with Aristotle's statement that 
'being is said in multiple ways'. In this statement, we have being, language ('being said'), and the event (the unfolding in multiple ways). As he describes it in a 1931 course (1995), the 'being said in multiple ways' is an 'unfolding' (Entfaltung) of being and the latter is a happening (Geschehen) (25). Thus, the unfolding of being or manifestation of being takes the form of a 'being said' or language and this unfolding-manifestation is history.

Heidegger's views on history (Geschichte), the event (Ereignis) or happening (Geschehen) have generated sharp oppositions among commentators: is Ereignis an 'appropriating event' (Dahlstrom 2013, 17; Polt 2006), an 'appropriation' (Wrathall 206), an 'en-owning' (Emad and Maly in Heidegger 1999, xix-xxii) or, more simply, an event (Vandevelde 2012; lyer, 2014) ? Is Geschichte 'history' or 'historiality' or 'historicality' (Pippin 212)? Is being 'history' itself or the entering into history? Is Ereignis more fundamental than being or is it another name for being (Capobianco 37)? Is there being only because there are human beings who could make sense of it so that being is the same as the meaning of being (Sheehan 2011, 1f)? My aim again is not to answer these questions, but only to delineate the stakes of these various possibilities of interpretation. With a focus on language, let us ask two questions: first, what does it mean that the 'being-said' is the unfolding of being, and second, what does it mean that the unfolding of being is a happening?

We can rephrase the first question about the 'being said' as asking about the connection that Heidegger establishes from early on between understanding something 'as' something and the possibility for something to have access to intelligibility and hence to become meaningful, so that a particular something 'is'. The 'as' - being understood 'as' something - is parallel to the 'is' that can be said about something. When we say 'is' we say 'we understand this entity "as" this or that.' Understanding constitutes the threshold of intelligibility at which point it can be said: it, this thing, is.

However, we are not in a utilitarian or pragmatic framework in which truth has a 'cash value', as James says. The saying as well as the understanding are not mere human activities or capacities. This is the object of our second question: the saying or the understanding are part of an event, the event of the unfolding of being. Heidegger places the multiplicity of saying or understanding being under the multiplicity of the unfolding of being itself: 'Thus, when Aristotle speaks of the multiplicity of the unfolding of beings as beings, he means the multiplicity of the unfolding of the being of beings. Being unfolds itself [faltet sich einander]' (1995, 11. Translation modified). The unfolding of being manifests itself in our 'saying' or 'understanding' or 'taking' beings but is not confined to our saying, understanding, or taking.

No matter how close a connection there may be between the 'is', which can be ascribed to a being, and the 'as', which results when we 'say' or 'understand' or 'take' beings, there is no equivalence - no idealism according to which we would prescribe the framework within which anything can be a 'something'; no pragmatism either (pace Okrent 1988), according to which we would appoint ourselves as the gate-keepers of being, assessing its cash value. Rather, and quite remarkably, as we saw, Heidegger characterizes this connection between 'is' and 'as' - something 'is' when it is understood 'as' something - as a 'happening' (Geschehen) or an event. Speaking about Aristotle's pollachos legetai, Heidegger raises the question: 'Might the unity of being lie precisely in this imparting parting out [mitteilenden Verteilung]? And if so, how would and could something like that happen [geschehen]? What holds sway in this event [was waltet in diesem Geschehen]?' $(1995,25)$. Keeping in mind the fact that the being-said of beings is the unfolding of being and, as such, a happening, in what sense is going through words - through the word 'woods' - such a happening? This is our second question.

It is obviously not a claim that thinking requires language as a mediation, such as we find in some areas of linguistics or in the philosophy of language of people like Peter Carruthers (1996) or John Searle (1985). It is not the view that, if we do not have words for some entities, they would not exist for us, as the Whorf-Sapir hypothesis holds (Whorf 1956). Or that language constrains our thinking even to the point that, in the terms of Roland Barthes, there is a 'fascism' in language. It is rather and again the connection between 'is' and 'as', the 
'as' being what words provide, but without equivalence between 'is' and 'as' or between language and being. Time is involved and is of the essence, as it were, and in the most literal sense: it is the event-character of the going-through the words. The going-through the words is a happening in the sense that the meaningfulness of my physical movements and gestures in the forest - even if I do not utter words, not even in inner speech - is provided by an articulation that is not merely a form of intent - my intent to go to the forest - nor merely an intention - my mental states of being directed at whatever catches my attention in the forest. But what is this articulation? In what sense does the happening 'articulate' anything?

This question asks about what exactly the connection is between being, understanding, and event, or between 'is', 'as', and happening (Geschehen). The logos is reversible, both as being-said and as unfolding, both as what beings are said to be and what makes them what they are, both of the order of language and of the order of being. The connection between 'is' (or being), 'as' (or language), and happening (or history) is even inscribed in the Greek word on (being), as Heidegger points out in a 1943-1944 course on Heraclitus. Heidegger reminds us that, for Aristotle and other Greek thinkers, what they question and investigate as 'being' is named in the participial form, to on, not in the infinitive form, to einai. As in English, beings are addressed adjectivally as 'being' the kind of beings they are. In German, das Seiende was originally understood as what is seiend. 'When the thinker thinks beings [das Seiende] he understands this participial word not in the substantive sense but in the verbal sense' (Heidegger 1987, 55). This means that the question of being does not ask 'whether beings are a stone or a bone or a donkey or a triangle, but the question asked by the thinker, "what are beings?" only has the meaning: what is the being of beings [was ist das Sein des Seiende?], what is that in which and through which something is "being" ['seiend' ist]? What characterizes in general the "being" [das 'Seiend'] as such?' (55).

Although Aristotle as well as Plato come to ask about the beingness (Seiendheit) of beings and thus, in some sense, miss the question of being, what is inceptual in their thinking - what belongs to the happening-character of their thinking - is that they think beings in the participial form. 'Thus, when the inceptual thinkers already say the words to on, ta onta, beings, they, as thinkers, think immediately in advance the "participial" word not substantively but verbally; to on, beings, are thought in the [adjectival] sense of being [Seiend], i.e., in the sense of being [Sein]' $(\mathbf{1 9 8 7}, 57-58)$. In other words and already within the framework of Greek thought, we can ask meaningfully about the 'being' of the tree in a twofold manner. We can ask, first, what is the being in the sense of the essence of the tree, i.e., its eidos, what metaphysics has done since Greek times. We can also ask, second, about what makes a tree what it is: not about its 'whatness' or treeness but about its beingness (Seiendheit). Plato already asks such a question in his theory of ideas. Or, third, we can ask the question of being in the sense of wondering where this 'beingness' comes from and in what kind of event it arose, whether what is taken to be for us was taken to be in the same sense by the ancient Greeks, for example. When asking such a question, we do not wonder what the essence of a tree is by looking at different trees (first question) nor about what makes possible the existence of trees as such delineated entities as opposed to another arrangement of matter. We ask a question that links together being (the 'what' and 'why' question), history (the beingness as part of a particular convergence of social, cultural, and political forces as opposed to an alleged atemporal scientific gaze), and language (the beingness as a particular articulation in a set of categories conveyed by particular natural languages like Greek, German, or English).

Because there is a moment of 'seiend' in Seiende - a moment of being, as a participle, in beings - we cannot simply equate beings with things as well-delineated entities. There is a process involved in the very being of a tree, namely a temporal process in at least two senses. First, there is a present as indicated by the verbal form the present participle - but also, second, there is another subtending temporality that encompasses the beingpresent of the tree and which Heidegger expresses in the Contributions as a 'becoming': being as an adjective both means 'being-tree' (Baum-seiend) and 'becoming-being' (seiend werden). In a simple 'being' like a tree, which is being-tree and becoming-being, the becoming points to an event or a happening in the tree's very 
presence. Different from the metaphysical becoming as a feature of being, which Heidegger criticizes in Introduction to Metaphysics, the becoming-being (seiend werden) 'is' being as a happening. It is not a happening that takes place in another container that would be called 'time' or 'history'. Rather, the happening of becoming-tree is actually the tree. Heidegger writes: 'Plant, animal, rock and sea and sky become beings [seiend werden]' $(1999,207)$.

We are also part of this becoming and happening. We are meaning-givers, but only subsidiarily as those who cope, manage, and respond. What Heidegger says about Hölderlin holds for us as well: what Hölderlin poeticized is not just what he meant, but rather 'what meant him [was ihn meinte] as what called him in this task of the poet [Dichtertum]' (Heidegger 1982, 13). Now, of course, we are the only ones who can ask the question. However, if we are ourselves 'configured', the questions we ask are always from within the happening and part of the becoming. The very framing of the question of being, thus, entails a displacement of human beings: we have to ask the question as if we were not those who question, but those who are put to the question; or we have to behave as investigators as if we were at the dative instead of the nominative or, as Emmanuel Levinas is fond of saying, as if we were at the accusative. We are respondent to an event within a happening.

This goes against our deep-seated, very modern inclination to take ourselves as the center of relationships. We take ourselves to be those who confer a meaning or for whom some relationship makes a difference (a tornado in the Midwest, because it affects us) and another does not (a three-month dust storm on Mars, because it leaves us indifferent and is insignificant, unless we have some 'presence' and stakes there). Thus, when asking the question of being, we are inclined to understand the sense or meaning of being as a sense for us, because we believe that we open the framework of intelligibility and that it is within this framework that there is being, that, literally, a tree 'is'. Remove any sense-giver and there is no one there to see the tree and the storm or to understand their sense or meaning, so there is then no room or framework for 'being'. The problem with such a common view is that it confines the question of being to the sense it makes to us so that no question can bear upon our very framework of intelligibility: for example, how such a framework came about, whether it can change, whether we, human beings, have changed in the course of time, etc. This is where the notion of happening shakes up any privilege human beings may claim as meaning-givers.

If we take seriously the following equivalence that Heidegger makes: 'a happening [Geschehen], our happening, the happening of the people, being' $(\mathbf{1 9 9 8}, \mathbf{1 1 6})$, there is a significant ontological uptake: if those who question are displaced through a happening and inserted into a process of 'becoming being', ontology does not have to abide by what we take to be the obvious 'delineations' or 'carving outs' of the world in terms of 'things', 'states of affairs', or even 'human beings'. The ontological alternative Heidegger offers - and it is an alternative ontology - is to shift the focus away from entities ('things') like 'well' or 'tree' toward their becoming-well or becoming-tree. In 1941, he calls this the 'gathering' that a thing can accomplish: a thing like a jug 'gathers' a world; it comes with a world. Take the world away, like the world of the temple at Paestum, and the temple becomes stilted, fodder for tourists, a 'has-been' (das Gewesene): it still is 'some thing', just not a temple anymore. The same holds for a thing like a tree. At its core, it has a fluidity that allowed it to be permeated by the gods (for the Greeks), to be a gift of a benevolent creator (for most of the middle ages), to be stuff that can be transformed (for our industries), or to be a unique component of an eco-system (for conservationists). Thus, when speaking of a being or a thing we are dealing with two different levels of description of what 'is'.

Heidegger's adjectival understanding of being yields the promise, through language and its connection to beings, thus through the connection between the 'as' and the 'is', to retrieve the seiend-moment in beings and thus to give us a glimpse into the fluidity itself. This glimpse reconnects us with the realm of the possibles, with the potentiality at the heart of reality, with the becoming in things. By paying attention to language, we may find an echo of the happening that went into beings and may thus be able to re-effectuate the beginning, to effectuate 'another' beginning by giving traction again to the happening. Heidegger explains this possibility in 
the Contributions as follows: 'But wherever plant, animal, rock and sea and sky become being [seiend werden], without falling into objectness, there withdrawal (refusal/not-granting) of be-ing reigns - be-ing as withdrawal' $(1999,207$. Translation modified). In other words, if we pay attention to the becoming in things, to their seiend moment - thus cultivating the happening in their arising into being, in the fact that they are - we are in tune with the beginning, we are attuned to the happening, or we think inceptually.

The way language helps us do this is through the reverse side of what it provides. As we saw in Aristotle's statement, the saying allows the 'is' through the 'as' of the understanding. However, this also means that, when said, beings lose their seiend moment; their becoming has been fixed into words, which as such preserve beings. 'Poetry makes beings more being [seiender]', Heidegger tells us $(\mathbf{1 9 8 8}, 64)$, not because it gives them an increase in relevance, beauty, effability and so on, but precisely because poetry breaks away from the language as commonly used. By breaking away from common language poetry allows the seiend moment to become perceivable or hearable again. This is why Heidegger so much enjoys the verse: 'May no thing be where the word breaks open' (kein Ding sei wo das Wort gebricht), which he understands in an apparently opposite manner to Stefan George when he glosses: 'an "is" is given when the word breaks open' $(1959,216)$. On the one hand, because the word fails, the connection between 'is' and 'as' loses its grip on reality: poetry, for example, may leave us stunned, speechless, not knowing what to say or to think. On the other hand, when the connection between 'is' and 'as' fails us, there is the possibility for another 'is' to arise. Just as to on means both becomingbeing - adjectivally understood - and 'a' or 'the' being - in its substantive form - the 'is' means: 'has been understood' and 'enters into being'. Thus, by failing the word unveils being in the negative sense of taking away the obviousness of what we take for granted, but also in the positive sense of allowing for new configurations to arise: a work of art can make us 'see' something as if for the first time. This is how 'the word gives: being' (1959, 193). The failing of words shows the happening precisely because 'it is only in the beginning that beings "become" [je nur im Anfang das Seiende "wird"]' (2005, 122). Language is the materialization or the crystallization or the falling into historical times of this becoming, turning the becoming into a being-a-thing. Because language is that in which 'the manifestness [Offenbarkeit] and the power of revelation [Kundschaft] of the world first of all burst forth and are' $(1995,109)$, it also means that language is the means for us to recover the potentiality in the world as revealed, to be sensitive to its susceptibility to be configured otherwise in seeing in things their 'becoming being'.

Language is the house of being by lending the becoming a historical configuration so that we can deal with the woods and the well, and use them, finding ourselves at home among them. However, language also reminds us that, by having become woods and well, things in fact bring together a particular world - they 'gather' a world and may take it away. The gathering of a world is in fact an event. Because language both made that possible and remains a testimony to this event, the being-at-home in language is always a going-home and the house of being is a journey, back to our province through the woods of the Black Forest or back to Ithaca through the sea.

The being-said of Heidegger's language - or any philosopher's language - is a performance that enacts a fusion between language, being, and the event. Interpreters, thus, cannot remain neutral observers abstracting from outside the text an alleged 'conceptual content' for the sake of 'intelligibility'. However, they cannot merely immerse themselves in the text, playing with its components as with pieces of a puzzle. If they want to keep the excitement of Heidegger's fascinating formulations while bringing intelligibility, they have to reject Davidson's assumption that both excitement and intelligibility come exclusively from the text. Interpreters have to accept wholeheartedly to act upon Heidegger's - or any philosopher's - performance, continuing the text and providing an articulation to the proposal Heidegger's language offers. It will be under their responsibility that language theirs and Heidegger's - reveals how 'things, each in its time, literally visit mortals with a world' (1971, 199200). 


\section{Acknowledgment}

I would like to thank Marisola Xhelili and Daniel Adsett for their editorial help.

\section{Works Cited}

Adorno, Theodor. The Jargon of Authenticity, trans. Knut Tarnowski and Frederic Will. Evanston, IL: Nortwestern University Press, 1973.

Allemann, Beda. 1954. Hölderlin und Heidegger. Zurich: Atlantis Verlag.

Apel, Karl-Otto. 1963. Die Idee der Sprache in der Tradition des Humanismus von Dante bis Vico. Archiv für Begriffsgeschichte. vol. 8. Bonn: Bouvier.

Apel, Karl-Otto. ' Sinnkonstitution und Geltungsrechtfertigung. Heidegger und das Problem der Transzendentalphilosophie.' Martin Heidegger: Innen- und Aussenansichten. Forum für Philosophie Bad Homburg. Frankfurt: Suhrkamp, 1989. 131- 175.

Benjamin, Walter. 'Die Aufgabe des Übersetzers.' Illuminationen, Ausgewählten Schriften I. Frankfurt: Suhrkamp, 1974.

Capobianco, Richard. Engaging Heidegger. Toronto: University of Toronto Press, 2010.

Carnap, Rudolf. ' The Elimination of Metaphysics Through Logical Analysis of Language.' Logical Positivism. Ed. A. J. Ayer. Glencoe, IL: The Free Press, 1959. 60- 81.

Carruthers, Peter. Language, Thought, and Consciousness: An Essay in Philosophical Psychology. Cambridge: Cambridge University Press, 1996.

Dahlstrom, Daniel. The Heidegger Dictionary. New York: Bloomsbury, 2013.

Davidson, Donald. ' On the Very Idea of a Conceptual Scheme.' Inquiries into Truth and Interpretation. Oxford: Clarendon Press, 1974. 183- 198.

De Man, Paul. ' Heidegger's Exegesis of Hölderlin.' Blindness and Insight: Essays in the Rhetoric of Contemporary Criticism. Minneapolis, MN: University of Minnesota Press, 1983. 246- 266.

Derrida, Jacques. 1982. Margins of Philosophy. Chicago: University of Chicago Press.

Derrida, Jacques. 1989. Of Spirit: Heidegger and the Question. Trans. Geoffrey Bennington and Rachel Bowlby. Chicago: University of Chicago Press.

Dreyfus, Hubert. 'Comments on Cristina Lafont's Interpretation of Being and Time.' Inquiry 45 (2002): $191-194$.

Hubert Dreyfus and Mark Wrathall, eds. Heidegger Reexamined. vol. 4. Language and the Critique of

Subjectivity. London: Routledge, 2002.

Frege, Gottlob. ' On Sense and Nominatum.' The Philosophy of Language. Ed. A. P. Martinich. Oxford: Oxford University Press, 2008. 217- 229.

Gadamer, Hans-Georg. Truth and Method. New York: Continuum, 1989.

Grass, Günter. Hunderjahre. Danziger Trilogie 3. Frankfurt: Hermann Luchterhand, 1963.

Heidegger, Martin. Unterwegs zur Sprache. Pfullingen: Neske, 1959.

Heidegger, Martin. Poetry, Language, Thought. Trans. Albert Hofstadter. New York: Harper and Row, 1971.

Heidegger, Martin. 'Brief über den 'Humanismus'.' Wegmarken. GA 9. Ed. Friedrich-Wilhelm

Herrmann. Frankfurt a.M.: Klostermann, 1976.

Heidegger, Martin. Hölderlins Hymne "Andenken." GA 52. Ed. Curd Ochwadt. Frankfurt am Main: Vittorio Klostermann, 1982.

Heidegger, Martin. Heraklit 1. Der Anfang des abendländischen Denkens; 2. Logik. Heraklits Lehre vom Logos. GA 55. 2nd ed. Ed. Manfred Frings. Frankfurt am Main: Vittorio Klostermann, 1987.

Heidegger, Martin. Vom Wesen der Wahrheit. Zu Platons Höhlengleichnis und Theätet. GA 34. Ed. Hermann Mörchen. Frankfurt am Main: Vittorio Klostermann, 1988.

Heidegger, Martin. Aristotle's Metaphysics IX 1-3: On the Essence and Actuality of Force. Trans. Walter Brogan and Peter Warnek. Bloomington: Indiana University Press, 1995.

Heidegger, Martin. Logik als die Frage nach dem Wesen der Sprache. GA 38. Ed. Günter Seubold. Frankfurt am Main: Klostermann, 1998. 
Heidegger, Martin. Contributions to Philosophy (From Enowning). Trans. Parvis Emad and Kenneth Maly. Bloomington: Indiana University Press, 1999.

Heidegger, Martin. Über den Anfang. GA 70. Ed. Paola-Ludovika Coriando. Frankfurt am Main: Klostermann, 2005.

Heidegger, Martin. 2012. Contributions to Philosophy: Of the Event. Trans. Richard Rojcewicz and Daniela Vallega-Neu. Bloomington: Indiana University Press.

Iyer, Arun. Heidegger and Foucault: Towards an Epistemology of Ruptures: The Case of Heidegger and Foucault. London: Bloomsbury, 2014.

Kuhn, Thomas. The Structure of Scientific Revolutions. Chicago: University of Chicago Press, 1962.

Lafont, Cristina. 2000. Heidegger, Language, and World-Disclosure. Trans. Graham Harman. Cambridge: Cambridge University Press.

Lohmann, Johannes. ' M. Heideggers ontologische Differenz und die Sprache.' Lexis. Studien zur Sprachphilosophie, Sprachgeschichte und Begriffsbildung, I, 1948. 49- 106.

Lyotard, Jean-François. The Postmodern Condition: A Report on Knowledge. Trans. Geoffrey Bennington and Brian Massumi. Minneapolis, MN: University of Minnesota Press, 1984.

Meschonnic, Henri. Le signe et le poème. Paris: Gallimard, 1975.

Okrent, Mark. Heidegger's Pragmatism: Understanding, Being, and the Critique of Metaphysics. Ithaca: Cornell University Press, 1988.

Pippin, Robert. ' Necessary Conditions for the Possibility of What Isn't: Heidegger on Failed Meaning.' Transcendental Heidegger. Eds. Steven Crowell and Jell Malpas. Stanford: Stanford University Press, 2007.

Polt, Richard. The Emergency of Being: On Heidegger's Contributions to Philosophy. Ithaca: Cornell University Press, 2006.

Jeffrey Powell, ed. Heidegger and Language. Bloomington, IN: Indiana University Press, 2013.

Rorty, Richard. Essays on Heidegger and Others. Cambridge: Cambridge University Press, 1991.

Scott, Chartles. 'Introduction: Approaching Heidegger's Contributions to Philosophy and its Companion.' Companion to Heidegger's Contributions to Philosophy. Eds. Charles Scott, Susan Schoenbohm, Daniela Vallega-Neu, and Alejandro Vallega. Bloomington, IN: Indiana University Press, 2001.

Searle, John. The Construction of Social Reality. New York: The Free Press, 1985.

Sheehan, Thomas. 'Astonishing! Things Make Sense!' Gatherings: The Heidegger Circle Annual 1 (2011): 1- 25.

Staiger, Emil. Basic Concepts of Poetics. Trans. Marianne Buchard and Luanne Frank. University Park: Pennsylvania State University Press, 1991.

Vandevelde, Pol. Heidegger and the Romantics: The Literary Invention of Meaning. New York: Routledge, 2012.

Vattimo, Gianni. The Adventure of Difference: Philosophy After Nietzsche and Heidegger. Cambridge: Polity Press, 1993.

Wandruzska, Mario. 'Etymologie et philosophie.' Etymologica. Walter von Wartburg zum siebzigsten Geburtstag 18. Mai 1978. Tübingen: Max Niemeyer, 1978.

Whorf, Benjamin. ' Languages and Logic.' Language, Thought, and Reality: Selected Writings of Benjamin Lee Whorf. Ed. J. B. Carroll. Cambridge, MA: MIT Press, 1956. 233- 245.

Wrathall, Mark. Heidegger and Unconcealment: Truth, Language, and History. New York: Cambridge University Press, 2011. 